\title{
Prevalence of Depression in Type 2 Diabetic Patients in Trinidad and Tobago \\ FT Frederick ${ }^{1}$, HD Maharajh ${ }^{2}$
}

\begin{abstract}
Background: Depression is a common problem among those suffering from diabetes mellitus. The dual diagnoses of a chronic medical disease and mental disorder, symptomatic presentation and stringent treatment regimen are sources of psychological distress for patients and present a major challenge for healthcare workers.

Method: In a cross-sectional study, one hundred and twenty-eight Type 2 diabetic patients were investigated for depression using the Zung Depression Scale. All cases were diagnosed by a physician and patients were selected from outpatient clinics of the four major hospitals in Trinidad. The Pearson product-moment correlation coefficient, stepwise multiple regression and t-test were utilized to examine the relationship between participant's age, gender, glucose control, coexisting medical complications and depression.

Results: The patients were primarily Indo-Trinidadians (49\%), over 50 years (79.7\%) and women $(60 \%)$. The prevalence of depression was $17.9 \%$ of Type 2 diabetic patients reporting mild to moderate levels of depression. Female Type 2 diabetics had higher scores of depression ( $M=42.13, S D=9.83$, $\mathrm{p}=0.011)$ than male Type 2 diabetics $(M=38.71, S D=8.9)$. Patients with coexisting medical complications had higher levels of depression $(M=44.01, S D=9.52)$ than those with diabetes alone $(M=37.74, S D=8.79, \mathrm{p}=0.000)$.

Conclusion: The prevalence of depression in Type 2 diabetic patients highlights the necessity for psychological screening at diabetic health clinics in Trinidad and Tobago, particularly for women and those with co-morbid medical complications. This will aid in better control, quality of life and longevity.
\end{abstract}

Keywords: Diabetes mellitus, depression, gender, Trinidad and Tobago

\section{Prevalencia de la Depresión en Pacientes con Diabetes Tipo 2 en Trinidad y Tobago}

\author{
FT Frederick ${ }^{1}$, HD Maharajh ${ }^{2}$
}

\section{RESUMEN}

\begin{abstract}
Antecedentes: La depresión es un problema común entre las personas que sufren de diabetes mellitus. El diagnóstico dual de una enfermedad médica crónica y un trastorno mental, la presentación sintomática y un régimen de tratamiento estricto, son fuentes de angustia psicológica para los pacientes y representan un reto importante para los trabajadores de la salud.

Método: En un estudio transversal, ciento veintiocho pacientes con diabetes tipo 2 fueron investigados en relación con estados depresivos, usando la Escala de Depresión de Zung. Todos los casos fueron diagnosticados por un médico, y los pacientes fueron seleccionados de clínicas ambulatorias de los cuatro hospitales principales en Trinidad. El coeficiente de correlación producto-momento de Pearson, la regresión gradual múltiple, y la prueba t, fueron utilizados para examinar la relación entre la edad del participante, el género, el control de la glucosa, las complicaciones médicas coexistentes, y la depresión.

Resultados: Los pacientes eran principalmente indotrinitenses (49\%), más de 50 años (79.7\%) y mujeres $(60 \%)$. La prevalencia de la depresión fue $17.9 \%$ de los pacientes diabéticos tipo 2 que reportaban niveles de depresión de leves a moderados. Las mujeres diabéticas tipo 2 tuvieron puntuaciones de depresión mayores $(M=42.13, S D=9.83, \mathrm{p}=0.011)$ en comparación con los hombres
\end{abstract}

From: ${ }^{1}$ Faculty of Medical Sciences and ${ }^{2}$ Department of Clinical Medicine, Mt Hope Hospital, Champ Fleurs, Trinidad and Tobago.
Correspondence: FT Frederick, Faculty of Medical Sciences, Mount Hope Hospital, Champs Fleurs, Trinidad and Tobago. E-mail: feliciafrederick@ live.com 
diabéticos tipo $2(M=38.71, S D=8.9)$. Los pacientes con complicaciones médicas coexistentes tenían niveles más altos de depresión $(M=44.01, S D=9,52)$ que aquellos sólo con diabetes $(M=37.74, S D$ $=8.79, \mathrm{p}=0.000$ ).

Conclusión: La prevalencia de la depresión en pacientes diabéticos tipo 2 señala la necesidad de realizar tamizajes psicológicos en las clínicas para diabéticos en Trinidad y Tobago, en particular para las mujeres y aquellos con complicaciones médicas comórbidas. Esto ayudará a un mejor control, calidad de vida y longevidad de los pacientes con diabetes tipo 2.

Palabras claves: Diabetes mellitus, depresión, género, Trinidad y Tobago

West Indian Med J 2013; 62 (7): 629

\section{INTRODUCTION}

Diabetes carries with it a considerable amount of trauma and depression. The diagnosis, symptomatology and stringent treatment regimes of diabetes mellitus can be a source of great psychological distress for patients $(1,2)$. A metaanalysis done in the United Kingdom of published articles between January 1980 and May 2005 found that the overall prevalence of depression in patients with Type 2 diabetes was $17.6 \%$, suggesting that approximately one in six people have Type 2 diabetes and are likely to experience depressive symptoms that may interfere with functional health (3).

Across the region, varying rates of depression among diabetics have been reported in chronic disease clinics. In Jamaica, Wilks and his colleagues found that diabetes mellitus was more prevalent among those with the characteristic symptoms of depression (4). In chronic disease clinics in Southwest Trinidad, Maharaj found the prevalence of depression to be $29.2 \%$ (5). In a cross-sectional survey of participants taken from various family practices in the NorthWest region of Trinidad, the same author reported that $13.8 \%$ of the cases of depression presented with diabetes mellitus (6).

The co-morbidity of depression and diabetes can have substantial and debilitating effects on a patient's health (7). Approximately $30 \%$ of adults with Type 2 diabetes have depression and this combination is linked to higher complication rates, poor glucose control, decreased quality of life and increased risk of death $(8,9)$.

De Groot and colleagues (10) found that depression was significantly associated with complications in diabetic patients. The presence of depression may affect the course of the development of complications by promoting the onset of some and intensifying others. Increase in depressive symptoms was associated with an increase in the severity or number of diabetes complications (10). A longitudinal study of 114 patients over a ten-year period found a three-fold increased likelihood of developing coronary artery disease in patients with depression (11).

Some of the risk factors for depression in Type 2 diabetics have been associated with female gender (12). The diagnosis of depression is approximately twice as likely in women as in men; one study reported that depression rates were $23.1 \%$ in diabetic women and $12.4 \%$ in diabetic men
(13). An Iranian study at a diabetes research centre found that depression was higher in diabetic women (28\%) compared to men [18\%] (14). Similarly, a Chinese study on the prevalence of depressive symptoms in Type 2 diabetics found that female gender was significantly and independently associated with depressive symptoms in Type 2 diabetics (15).

Patient's age has been associated with depression in Type 2 diabetics; however, there is no consensus on which age group is a major risk factor for depression in Type 2 diabetics. Some researchers found that the age group 31-59 years had higher prevalence of depression, while dysthymia was more frequent in those over 60 years old (12). In other studies, older persons with diabetes were at increased risk of depression (16). Of the old age diabetics, age 60-80 years, $26.0 \%$ reported elevated depressive symptoms.

A number of studies have indicated that depressive disorder is more frequent in diabetic patients with poor glycaemic control than in those with good glycaemic control (17). Lustman and colleagues (18) found that depression is associated with hyperglycaemia in patients with Type 2 diabetes. Similarly, a study of veterans with Type 2 diabetes demonstrates that there is a significant longitudinal relationship between depression and glycaemic control and that depression is associated with persistently higher glucose levels over time (9).

The purpose of this study is to investigate the prevalence of depression in Type 2 diabetic patients in outpatient clinics in Trinidad and to identify associated contributory factors. On the background of inconsistent rates of depression (13.8\% to $29.2 \%)$, it highlights the importance of this study that seeks to emphasize the psychological symptoms of diabetes present in clinical practice in Trinidad. As far as we can tell, this is the first study in the Caribbean that investigates the rate of depression in diabetic-outpatient clinics. Others have utilized chronic disease and family practice clinics.

\section{SUBJECTS AND METHOD}

This study utilized a cross-sectional research design to describe the statistical prevalence of depression in Type 2 diabetes. Diabetic outpatient clinics from four hospitals (Port-of-Spain General Hospital, Eric Williams Medical 
Science Complex, San Fernando General Hospital and Sangre Grande General Hospital) from each Regional Health Authority in Trinidad were used. These hospitals were selected because they have well-established chronic disease clinics and are widely distributed within Trinidad to represent the population including the different ethnic groups. The questionnaires were administered between July and August 2009. The Ethics Committee of the Faculty of Medical Sciences of The University of the West Indies, St Augustine, provided approval for this study prior to data collection.

Depression was determined using the Zung Depression Self-rating Scale (19). The items on the Zung Depression Scale measure the affective, behavioural and physiological aspects of depression. The questionnaire takes 10 minutes to complete and items are framed in terms of positive and negative statements. A cut-off point of 50 to 59 indicates mild depression, 60 to 69 indicates moderate depression and over 70 indicates severe depression.

Participants were recruited while attending their routine clinic appointment at the hospital. Participants provided verbal consent to partake in the research by agreeing to complete an anonymous questionnaire. Additional data were collected with regard to patients' demographic information, duration of diagnosis, use of alcohol and drugs and their present blood glucose level. Patients diagnosed with Type 1 diabetes, under the age of 21 years, diagnosis of less than a year and pregnant women were excluded from the research.

Descriptive and frequency statistics were calculated. Linear multiple regression was used to determine the independent predictor of depression in this population. The Pearson product-moment correlation coefficient was used to measure the correlation between the independent variables and dependent variables. The independent sample $t$-test was used to compare the means of the categorical independent variables of gender, age, glucose levels and coexisting medical complications based on depression scale scores. Data analysis was done using the Statistical Package for Social Sciences (SPSS, version 13).

\section{RESULTS}

Completed questionnaires were collected from 128 individuals with Type 2 diabetes at outpatient clinics in Trinidad. The overall response rate was $85 \%$. The majority of the participants were female $(60 \%)$, Indo-Trinidadian (49\%), over the age of 50 years $(79.7 \%)$, classified as unskilled or social class $5(43 \%)$ and diagnosed between 1 and 10 years ago $(82 \%)$.

Statistical analysis indicated the $17.9 \%$ of this population had mild to moderate levels of depression. The results of the Pearson $r$ analysis showed a moderate positive correlation between gender and depression $(r=0.22 ; p=0.011)$. The independent sample $t$-test showed that female Type 2 diabetics $(M=43.13, \mathrm{SD}=9.83)$ were more likely to be depressed than males $(M=38.71, \mathrm{SD}=8.93)$. In addition, correlation analysis showed a moderate negative significant correlation between coexisting medical complication and depression $(r=-0.32, p=0.000)$. The $t$-test analysis showed that patients with coexisting medical complications $(M=$ $44.01, \mathrm{SD}=9.52)$ had higher rates of depression than those with diabetes alone $(M=37.74, \mathrm{SD}=8.79)$. Hypertension $(15 \%)$ and heart conditions $(11 \%)$ were the two common coexisting medical complications among depressed Type 2 diabetics. Females, patients over 60 years old, diagnosed between one and 10 years ago, housewives or unskilled workers and being of East-Indian descent were also associated with depression.

No significant associations were found for age and depression $(p=0.13)$ and for glucose control and depression $(p=0.28)$.

Stepwise multiple regression analysis indicated that the independent predictors of depression in this population were gender and coexisting medical complication. For every increase in female Type 2 diabetics, an expected 4.1 point increase in depression is predicated. Additionally, an increase in patients with non-existing medical complications predicted a decrease in depression scores.

\section{DISCUSSION}

In this study, the prevalence rate of depression among Type 2 diabetic patients in Trinidad was found to be $17.9 \%$. This is comparable to international studies (3) but differs from research previously done in Trinidad (5). Possible reasons for the differences in rate could be attributed to the population sample utilized. Participants were mostly taken from a specific geographical area in Trinidad in chronic disease clinics, while the present sample was recruited from diabetic clinics across the country. In addition, the present study's prevalence estimates were higher than figures reported by Maharaj (13.8\%) in 2007 (6). Difference in estimate figures could be attributed to the social profiling or social class status of participants. Diabetic patients of a higher social class status would seek private care as opposed to public healthcare.

The prevalence of depression was more common in Type 2 diabetic women $(22.1 \%)$ than men $(11.7 \%)$. These findings are consistent with international findings of Type 2 diabetic women who are twice as likely to report higher levels of depression than men (13). In addition, coexisting medical complications were significantly associated with depression and anxiety among Type 2 diabetic patients. The literature shows that depression is common in patients with diabetes mellitus and has a negative impact on diabetes selfcare, adherence to treatment and the development of complications (20).

There is no consensus on the prevalence of depression among a particular age group of diabetics. The present study indicates that age as a variance is not significantly associated with the prevalence of depression in Type 2 diabetic patients. Type 2 diabetics of all ages usually find it upsetting to discover and be reminded daily that they have a serious, life- 
threatening condition that will not disappear (21). Daily sensitization of tragic complications such as amputation, renal failure, heart attacks and other systemic diseases perpetuates a chronic depression with an unresolved grief reaction.

Unlike other reports (17), this study found that glucose control was not significantly associated with levels of depression in this sample of Type 2 diabetic patients. However, Kruse and colleagues (22) in their study did not find a positive association between depression and glucose levels in a community sample. Another study found that individuals with diabetes and normal glucose level often had affective disorders than diabetics with poor glycaemic control (23). The inconsistencies of these findings may be explained by the observations that many patients become more compliant a few days before they come to the clinic. In addition, the emotions vested in coming to the clinic, the waiting time and the attitude of the staff will affect blood glucose levels.

In conclusion, the high percentage of depression in Type 2 diabetic patients in Trinidad raises the important question of the treatment of psychological and behavioural disorders. This will allow for a holistic approach for the management of Type 2 diabetes with a better outcome for patients.

\section{REFERENCES}

1. Macrodimitris SD, Endler NS. Coping, control and adjustment in Type 2 diabetes. Health Psychology 2001; 20: 208-16.

2. Lustman PJ. Anxiety disorders in adults with diabetes mellitus. Psychiatric Clin North Am 1988; 11: 419-32.

3. Ali S, Stone A, Peters JL, Davies MJ, Khunti K. The prevalence of comorbid depression in adults with type 2 diabetes: a systematic review and meta-analysis. Diabetes Med 2006; 23: 1165-73.

4. Wilks R, Younger N, Ashley D, Ward E, Mullings J, Forrester TE. The occurrence of depressive symptoms and the association with diabetes mellitus and hypertension in Jamaica. West Indian Med J 2002; 51 (Suppl 4): 15 .

5. Maharaj RG, Reid SD, Misir A, Simeon DT. Depression and its associated factors among patients attending chronic disease clinics in Southwest Trinidad. West Indian Med J 2005; 54: 369-74.

6. Maharaj RG. Depression and the nature of Trinidadian family practice: a cross-sectional study. BMC Family Practice 2007; 8: 25-30.
7. Landel Graham J, Yount SE, Rudnicki SR. Diabetes melltius. In: Nezu AM, Nezu CM, Geller P, Weiner I, eds. Handbook of Psychology: Health Psychology. New Jersey: John Wiley and Sons Inc; 2003: 191218.

8. Egede LE, Zheng D. Independent factors associated with major depressive disorder in a national sample of individuals with diabetes. Diabetes Care 2003; 26: 104-11.

9. Richardson LK, Egede LE, Mueller M, Echols CL, Gebregziabher M. Longitudinal effects of depression on glycemic control in veterans with Type 2 diabetes. General Hospital Psychiatry 2008: 30: 509-14.

10. De Groot M, Anderson R, Freedland KE, Clouse RE, Lustman PJ. Association of depression and diabetes complications: a meta-analysis. Psychosomatic Med 2001; 63: 619-30.

11. Talbot F, Nouwen A. A review of the relationship between depression and diabetes in adults. Diabetes Care 2000; 23: 1556-62.

12. Larijani B, Khoran M, Bayat S, Gorgani MK, Banderian F, Akhondzadeh $\mathrm{S}$ et al. Association between depression and diabetes. German J Psychiatry 2004; 7: 62-5.

13. Nichols GA, Brown JB. Unadjusted and adjusted prevalence of diagnosed depression in type 2 diabetes. Diabetes Care 2003; 26: 744-9.

14. Shansaei F, Cheraghi F, Allahverdipour H. Depression in diabetic patients. J Res Health Sci 2006; 16: 39-43.

15. Lin X, Ren J, Cheng M, Tang K, Dong M, Hou X et al. Depressive symptoms and risk factors in Chinese people with type 2 diabetes. Arch Med Res 2004; 35: 301-7.

16. Chou KL, Chi I. Prevalence of depression among elderly Chinese with diabetes. Int J Geriatr Psychiatry 2005; 20: 570-5.

17. Eren I, Erdi O, Ozcankaya R. Relationship between blood glucose control and psychiatric disorders in type II diabetic patients. Turkish $\mathrm{J}$ Psychiatry 2003; 14: 184-91.

18. Lustman PJ, Freeland KE, Griffith LS, Clouse RE. Fluoxetine for depression in diabetes: randomized double-blind placebo-controlled trial. Diabetes Care 2000; 23: 618-23.

19. Zung WWK. A self-rating depression scale. Arch Gen Psychiatry 1965; 12: $63-70$.

20. Struijs JN, Baan CA, Schellevis FG, Westert GP, Van den Boss GAM. Comorbidity in patients with diabetes mellitus: impact on medical health care utilization. BMC Health Serv Res 2006; 6: 84

21. Holmes D. Diabetes in its psychosocial context. In: Marble A, Krall LP, Bradley RF, Christlieb AR, Soeldner JS. Joslin's Diabetes Mellitus. Philadelphia: Lea and Febiger; 1985: 882-906.

22. Kruse J, Schmitz N, Thefeld W. On the association between diabetes and mental disorders in a community sample. Results from the German National Health Interview and Examination Survey. Diabetes Care 2003; 26: 1841-6.

23. Engum A, Mykletun A, Midthjeu K, Holen A, Dahl A. Depression and diabetes. A large population-based study of sociodemographic, lifestyle and clinical factors associated with depression in Type 1 and Type 2 diabetes. Diabetes Care 2005; 28: 1904-9. 